\title{
$\beta$-Elemene Enhances the Sensitivity of Osteosarcoma Cells to Doxorubicin via Downregulation of Peroxiredoxin-I
}

\author{
Shaochun Zhang ${ }^{1,2}$ \\ Weichun Guol \\ 'Department of Orthopedics, Renmin \\ Hospital of Wuhan University, Wuhan, \\ Hubei, 430060, People's Republic of \\ China; ${ }^{2}$ Department of Orthopedics, \\ Ezhou Central Hospital, Ezhou, Hubei, \\ 436000, People's Republic of China
}

Correspondence: Weichun Guo Department of Orthopedics, Renmin Hospital of Wuhan University, 238 jiefang Road, Wuhan, Hubei, 430060, People's Republic of China

Email guoweichun321@126.com
Background: Doxorubicin (Dox) resistance is a primary obstacle for the treatment of osteosarcoma. Meanwhile, $\beta$-Elemene was shown to exhibit an anti-proliferative effect on osteosarcoma cells. However, the role of a combination of Dox with $\beta$-Elemene on osteosarcoma cells remains unclear. Thus, this study aimed to investigate the role of the combination of Dox with $\beta$-Elemene on the proliferation, apoptosis and oxidative stress of Dox-resistance osteosarcoma cells.

Methods: CKC-8, EdU staining and flow cytometry assays were used to determine the viability, proliferation and apoptosis of Dox-resistance osteosarcoma cells, respectively. Meanwhile, the expression of antioxidant protein peroxiredoxin-1 (Prx-1) in Doxresistance osteosarcoma cells was detected with Western blot assay.

Results: In this study, the inhibitory effects of Dox on the viability and proliferation of Doxresistance osteosarcoma cells were significantly enhanced by $\beta$-Elemene. In addition, the combination of Dox and $\beta$-Elemene markedly induced the apoptosis and oxidative stress in Dox-resistance osteosarcoma cells. Moreover, combination treatment notably downregulated the expression of Prx-1 in Dox-resistance osteosarcoma cells, indicating that combination treatment inhibited the antioxidant capacity of Dox-resistance osteosarcoma cells. In vivo experiments confirmed that $\beta$-Elemene could enhance the anti-tumor effect of Dox in Saos-2/ Dox xenograft model.

Conclusion: We found that $\beta$-Elemene could reverse Dox resistance in Dox-resistance osteosarcoma cells via inhibition of Prx-1. Therefore, combining Dox with $\beta$-Elemene might be considered as a therapeutic approach for the treatment of Dox-resistant osteosarcoma.

Keywords: osteosarcoma, doxorubicin, $\beta$-Elemene, resistance, apoptosis

\section{Introduction}

Osteosarcoma is the most common primary malignant tumor of bone among children and adolescents, and it is characterized by high metastatic potential. ${ }^{1,2}$ In addition, osteosarcoma is associated with a high rate of morbidity and mortality worldwide. ${ }^{3}$ Recently, surgery, new adjuvant chemotherapy, immunotherapy and gene therapy are the main clinical therapies for the treatment of osteosarcoma. ${ }^{4,5}$ However, the early prognosis of osteosarcoma is still poor with the 5-year survival rate of about $50 \%{ }^{6,7}$ Evidence has shown that drug resistance in osteosarcoma cells is one of the most important factors affecting prognosis. ${ }^{8,9}$ Therefore, the development of novel effective therapeutic methods may help to prevent drug resistance in cancer chemotherapy. 
Doxorubicin (Dox) is the first-line chemotherapy agent used for the treatment of multiple solid tumors including osteosarcoma. $^{10,11}$ Although single-drug chemotherapy can improve the survival rate of cancer patients, it also brings about some adverse effects for cancer patients. ${ }^{12}$ Evidence has shown that the combination of two anticancer drugs in cancer therapies can diminish the adverse effects and suppress the occurrence of drug resistance. ${ }^{12}$

$\beta$-Elemene, a compound extracted from the traditional Chinese medicinal herb Radix curcumae, exhibited antitumor and chemo-preventive effects. ${ }^{13,14}$ Liang et al found that $\beta$-Elemene could inhibit the proliferation and induce the apoptosis of osteosarcoma cells. ${ }^{15}$ In addition, Tang et al indicated that $\beta$-Elemene could reverse Dox resistance in human breast cancer. ${ }^{16}$ However, the role of $\beta$ Elemene in Dox-resistance osteosarcoma cells remains unclear. Thus, in this study, we aimed to investigate whether $\beta$-Elemene could enhance the anti-tumor effect of doxorubicin on Dox-resistant osteosarcoma cells with the purpose of providing a promising therapeutic approach for cancer treatment.

\section{Materials and Methods}

\section{Cell Culture and Transfection}

Human osteosarcoma cell lines MG63, Saos-2 and U-2 OS were purchased from the Type Culture Collection of the Chinese Academy of Sciences (Shanghai, China). Three Dox-resistant osteosarcoma cell lines (MG63/Dox, Saos-2/ Dox and U-2 OS/Dox) were generated from parental MG63, Saos-2 and U-2 OS cells by gradually treating them with increasing doses of Dox for more than 3 months. Cells were cultured in Dulbecco's modified Eagle's medium (Thermo Fisher Scientific, Inc., Waltham, MA, USA) with $10 \%$ fetal bovine serum (Thermo Fisher Scientific) in an incubator with $5 \% \mathrm{CO}_{2}$ at $37^{\circ} \mathrm{C}$.

Human Prx-1 cDNA was synthesized and cloned into pcDNA3.1 vector. Then, MG63/Dox and Saos-2/Dox cells were transfected with pcDNA3.1 pcDNA3.1-Prx-1 plasmids using the Lipofectamine 2000 kit (Thermo Fisher Scientific).

\section{Cell Counting Kit-8 (CCK-8) Assay}

Cell Counting Kit-8 (CCK-8, Dojindo, Japan) was used to evaluate the cell viability according to the manufacturer's instructions. Cells were plated onto a 96-well plate at a density of 5000 cells per well and incubated overnight at $37^{\circ} \mathrm{C}$. After that, cells were treated with different concentrations of Dox $(0,0.5,2,5,25$ or $50 \mu \mathrm{g} / \mathrm{mL})$ or $\beta$ Elemene $(0,25,50,100$ or $200 \mu \mathrm{g} / \mathrm{mL})$ for $48 \mathrm{~h}$. Later on, $10 \mu \mathrm{L}$ CCK-8 reagent was added into each well, followed by incubation for $2 \mathrm{~h}$ at $37^{\circ} \mathrm{C}$. Subsequently, the optical density at $450 \mathrm{~nm}$ was detected using a microplate reader (BioTek, Winooski, VT, USA).

\section{Combination Studies}

The combination index (CI) for drug combination was determined using Chou-Talalay method. ${ }^{17}$ MG63/Dox and Saos-2/Dox cells were exposed to solutions containing Dox $(0,0.5,2,5,25$ or $50 \mu \mathrm{g} / \mathrm{mL})$ combined with $\beta$ Elemene ( 0 or $25 \mu \mathrm{g} / \mathrm{mL}$ ). The CI value for the combination of Dox and $\beta$-Elemene in Dox-resistant osteosarcoma cells can be described as $\mathrm{CI}=\mathrm{DA} / \mathrm{ICx}, \mathrm{A}+\mathrm{DB} / \mathrm{ICx}, \mathrm{B} .{ }^{17}$

\section{EdU Staining Assay}

Cell proliferation was determined using a Cell-Light EdU DNA Cell Proliferation Kit (Ribobio, Guangzhou, China). Cells were incubated with $50 \mu \mathrm{M}$ EdU reagent for $2 \mathrm{~h}$, and then fixed in 4\% paraformaldehyde. After that, cells were stained with Apollo reagent for $30 \mathrm{~min}$ at room temperature. Subsequently, the EdU-positive cells were observed under a microscope (Olympus, Tokyo, Japan).

\section{Flow Cytometry Assay}

Cell apoptosis was assessed using the Annexin V-FITC/PI double-staining cell apoptosis detection kit (KeyGEN BioTECH, Nanjing, China). Cells were collected and resuspended in $500 \mu \mathrm{L}$ binding buffer. After that, cells were stained with $5 \mu \mathrm{L}$ Annexin V-FITC and $5 \mu \mathrm{L}$ PI for 20 min in darkness at room temperature. Later on, cell apoptosis was measured using a FACSCalibur instrument (BD Biosciences, Franklin Lake, NJ, USA).

\section{Western Blot Assay}

Protein concentration was measured using a BCA Protein Assay Kit. Equal amounts of protein $(30 \mu \mathrm{g}$ protein/line) were separated by $10 \%$ SDS-PAGE and then transferred onto a PVDF membrane (Millipore, Billerica, MA, USA). After that, the membrane was blocked with $5 \%$ fat-free milk in TBST for $1 \mathrm{~h}$ at room temperature and then incubated with primary antibodies overnight at $4^{\circ} \mathrm{C}$. Antibody specific to Bcl2 (1:1000), Bax (1:1000), cleaved caspase 3 (1:1000), Prx-1 (1:1000), p-ERK (1:1000), ERK (1:1000), p-p38 (1:1000), p38 (1:1000), and $\beta$-actin (1:1000) were purchased from Abcam (Cambridge, MA, USA). Later on, the membrane was incubated with anti-rabbit horseradish peroxidase- 
conjugated secondary antibodies for $1 \mathrm{~h}$ at room temperature. Subsequently, protein bands were visualized by using the enhanced chemiluminescence (ECL) reagents (Thermo Fisher Scientific).

\section{Measurement of Reactive Oxidative Species (ROS)}

The peroxide-sensitive fluorescent probe 2, 7-dichlorofluorescin diacetate (DCFH-DA) was used to assess intracellular ROS. Cells were incubated with DCFH-DA for 30 min in darkness at $37^{\circ} \mathrm{C}$. Later on, the fluorescent signals were detected by flow cytometry (BD Biosciences).

\section{ELISA Assay}

Samples of the supernatants were collected from MG63/Dox and Saos-2/Dox cells. After that, the commercial ELISA kit (\#A006, Jiancheng, Bioengineering Institute, Nanjing, China) was used to measure the total quantities of glutathione.

\section{Animal Study}

BALB/c nude mice (6-8 weeks old) were purchased from Shanghai Slac Laboratory Animal Co., Ltd. (Shanghai, China). The animal studies were approved by the Institutional Animal Care and Use Committee of Renmin Hospital of Wuhan University Renmin Hospital of Wuhan University (NO. 2019041428A), and the guidelines for welfare and treatment of the laboratory animals were following to National Institutes of Health guide for the care and use of laboratory animals. $1 \times 10^{7}$ Saos-2/Dox cells (in $100 \mu \mathrm{L}$ of PBS) were injected into the left flank of each mouse. When the average tumor volumes reached $200 \mathrm{~mm}^{3}$, tumor-bearing mice were randomly divided into four groups: control, Dox, $\beta$-Elemene, $\beta$-Elemene + Dox groups. The $\beta$-elemene group was treated by intraperitoneal injection with $0.1 \mathrm{~mL} \beta$ Elemene $(45 \mathrm{mg} / \mathrm{kg})$ once daily for 3 weeks. Dox was administered via intravenous (i.v.) injection at doses of $5 \mathrm{mg} / \mathrm{kg}$ once a week. The control group received PBS only. After 3 weeks, all animals were sacrificed under anesthesia, and tumor tissues were weighted. Then, the tumor tissues were fixed and embedded in paraffin for immunohistochemistry (IHC) staining.

\section{Statistical Analysis}

Statistical analyses were performed with GraphPad Prism 7 (GraphPad Software, Inc., La Jolla, CA, USA). Data were represented as mean \pm standard deviation (SD). The comparisons among multiple groups were made with a oneway analysis of variance (ANOVA) followed by Tukey's test. All experiments were repeated at least three times. $\mathrm{P}<0.05$ was accepted as a statistically significant difference.

\section{Results}

\section{$\beta$-Elemene Enhanced the Cytotoxic Effect of Dox in Dox-Resistant Osteosarcoma Cells}

CCK-8 assay was used to assess the effects of Dox on the viability of Dox-sensitive or -resistance osteosarcoma cells. As shown in Figure 1A and B, MG63/Dox cells and Saos-2/Dox cells were resistant to Dox after gradient treatment compared with MG63 and Saos-2 parental cells. In addition, $\beta$-Elemene inhibited the viability of MG63, MG63/Dox cells, and Saos-2, Saos-2/Dox cells in a dosedependent manner (Figure 1C and D). Significantly, combining Dox with $\beta$-Elemene inhibited the viability of MG63/Dox and Saos-2/Dox cells, compared with Dox alone treatment group (Figure 1E and F). Combined Dox with $\beta$-Elemene exhibited similar effects on U-2 OS/Dox cell viability (Supplementary Figure 1A).

Furthermore, the $\mathrm{IC}_{50}$ value of Dox was $32.67 \mu \mathrm{g} / \mathrm{mL}$ and $44.16 \mu \mathrm{g} / \mathrm{mL}$ in MG63/Dox and Saos-2/Dox cells, respectively. However, when Dox was combined with $\beta$ Elemene $(25 \mu \mathrm{g} / \mathrm{mL})$, the $\mathrm{IC}_{50}$ value of Dox was decreased to $7.75 \mu \mathrm{g} / \mathrm{mL}$ and $7.22 \mu \mathrm{g} / \mathrm{mL}$ in MG63/Dox and Saos-2/ Dox cells, respectively (Table 1 ). In addition, the CI values of Dox with $\beta$-Elemene in MG63/Dox and Saos-2/Dox cells were 0.42 and 0.30 , respectively, indicating the synergistic activity (Table 1 ). These data indicated that the combination of Dox with $\beta$-Elemene synergistically inhibited the viability of Dox-resistant osteosarcoma cells

\section{Combination of Dox with $\beta$-Elemene Inhibited the Proliferation and Induced the Apoptosis of Dox-Resistant Osteosarcoma Cells}

To investigate the role of Dox and $\beta$-Elemene on the proliferation of osteosarcoma cells, EdU staining assay was used. As shown in Figure 2A and B, the combination of Dox with $\beta$-Elemene markedly inhibited the proliferation of MG63/ Dox and Saos-2/Dox cells, compared with Dox alone treatment group. In addition, the results of flow cytometry assay indicated that Dox treatment led to a marked increase in cell apoptosis (Figure 3A and B, and Supplementary Figure 1B). As expected, the combination of Dox with $\beta$-Elemene 
A

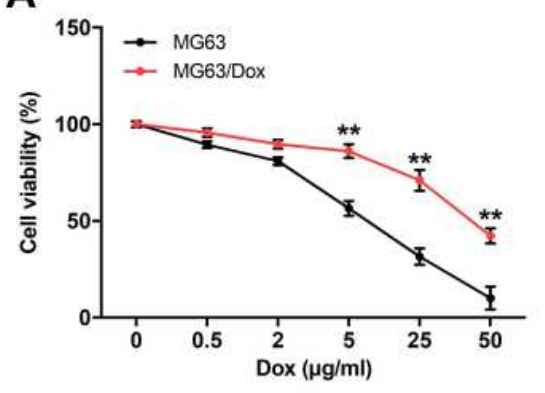

D

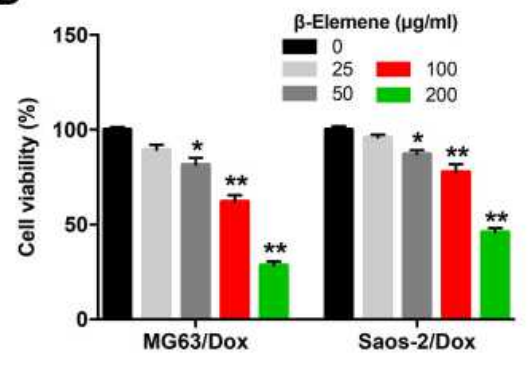

B
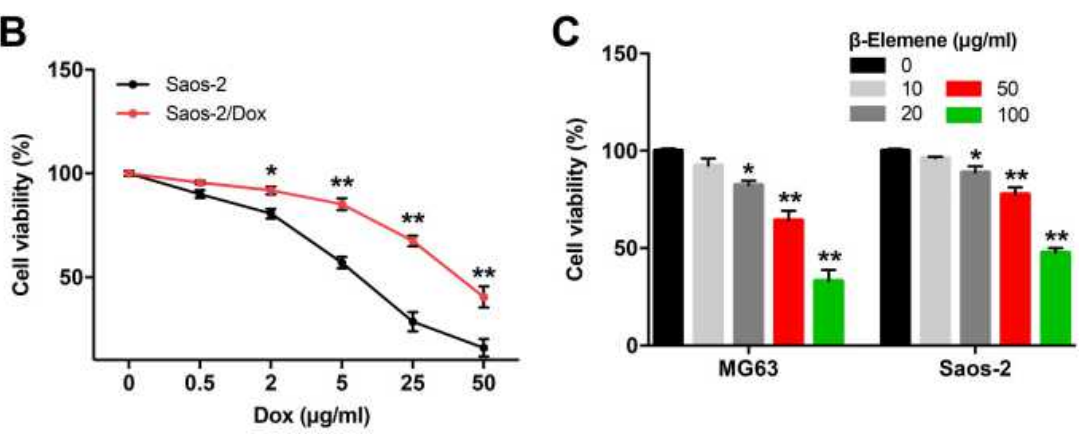

E

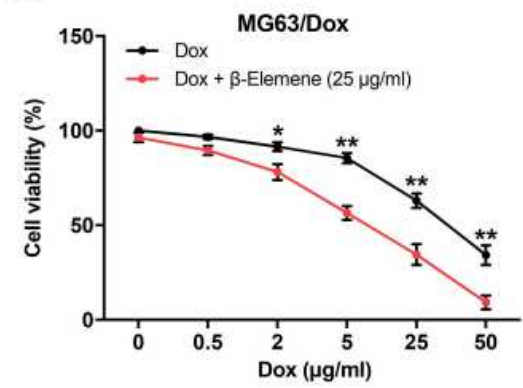

F

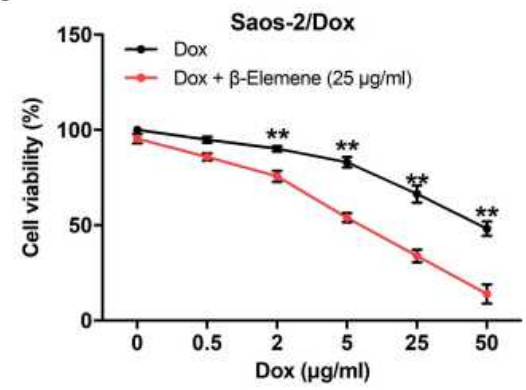

Figure I $\beta$-Elemene enhanced the cytotoxic effect of Dox in Dox-resistant osteosarcoma cells. (A) MG63 and MG63/Dox cells or (B) Saos-2 and Saos-2/Dox cells were treated with 0, 0.5, 2, 5, 25 or $50 \mu \mathrm{g} / \mathrm{mL}$ Dox for $48 \mathrm{~h}$ respectively. CCK-8 assay was used to detect cell viability. **P < $0.0 \mathrm{I}$, compared with the MG63 or Saos-2 group. (C) MG63 and Saos-2 cells were treated with $0,5,10,20,50$ or $100 \mu \mathrm{g} / \mathrm{mL} \beta$-Elemene for $48 \mathrm{~h}$ respectively. CCK-8 assay was used to detect cell viability. $* \mathrm{P}<0.05$, **P $<0.0 \mathrm{I}$, compared with the $\beta$-Elemene $(0 \mu \mathrm{g} / \mathrm{mL})$ group. (D) MG63/Dox and Saos-2/Dox cells were treated with $0,25,50,100$ or $200 \mu \mathrm{g} / \mathrm{mL} \beta$-Elemene for $48 \mathrm{~h}$ respectively. CCK-8 assay was used to detect cell viability. $* \mathrm{P}<0.05$, $* * \mathrm{P}<0.01$, compared with the $\beta$-Elemene $(0 \mu \mathrm{g} / \mathrm{mL})$ group. (E) MG63/Dox cells or (F) Saos-2/Dox cells were treated with $\operatorname{Dox}(0,0.5,2,5,25$ or $50 \mu \mathrm{g} / \mathrm{mL})$, or Dox $(0,0.5,2,5,25$ or $50 \mu \mathrm{g} / \mathrm{mL})$ plus $25 \mu \mathrm{g} / \mathrm{mL} \beta$-Elemene for 48 h. CCK-8 assay was used to detect cell viability. $* \mathrm{P}<0.05$, $* * \mathrm{P}<$ 0.01 , compared with the Dox treatment group.

Abbreviations: Dox, doxorubicin; MG63/Dox, Dox-resistant MG63 cells; Saos-2/Dox, Dox-resistant Saos-2 cells.

induced a substantial fraction of apoptosis in MG63/Dox, Saos-2/Dox and U-2 OS/Dox cells, compared with Dox alone treatment group (Figure $3 \mathrm{~A}$ and $\mathrm{B}$, and Supplementary Figure 1B). Moreover, the combination of Dox with $\beta$-Elemene treatment notably decreased the expression of Bcl-2, and markedly increased the expressions of Bax and cleaved caspase 3 in MG63/Dox and Saos-2/Dox cells, compared with Dox alone treatment group (Figure 3C-F). Meanwhile, $\beta$-Elemene significantly decreased the expressions of p-ERK and p-p38 in MG63/Dox and Saos-2/Dox cells (Supplementary Figure 2A-C). To sum up, combination

Table I Evaluation of Combination of Dox with $\beta$-Elemene in MG63/Dox and Saos-2/Dox Cells (48 h Treatment)

\begin{tabular}{|l|c|c|c|c|}
\hline \multirow{2}{*}{$\begin{array}{l}\text { Drug } \\
\text { Combination }\end{array}$} & \multicolumn{2}{|c|}{ MG63/Dox Cells } & \multicolumn{2}{c|}{ Saos-2/Dox Cells } \\
\cline { 2 - 5 } & $\begin{array}{c}\text { IC 50 } \\
\text { Value }\end{array}$ & $\begin{array}{c}\text { Cl } \\
\text { Values }\end{array}$ & $\begin{array}{c}\text { IC 50 } \\
\text { Value }\end{array}$ & $\begin{array}{c}\text { Cl } \\
\text { Values }\end{array}$ \\
\hline $\begin{array}{l}\text { Dox (range 0 } \\
\text { from } 50 \mu g / \mathrm{mL})\end{array}$ & $\begin{array}{c}\text { IC50 = } \\
32.67 \mu g / \mathrm{mL}\end{array}$ & - & $\begin{array}{c}\text { IC50 } \\
44.16 \mu g / \mathrm{mL}\end{array}$ & - \\
\hline $\begin{array}{l}\text { Dox }+25 \mu \mathrm{g} / \mathrm{mL} \\
\beta \text {-Elemene }\end{array}$ & $\begin{array}{c}\mathrm{IC} 50= \\
7.75 \mu g / \mathrm{mL}\end{array}$ & 0.42 & $\begin{array}{c}\mathrm{IC} 50= \\
7.22 \mu g / \mathrm{mL}\end{array}$ & 0.30 \\
\hline
\end{tabular}

of Dox with $\beta$-Elemene could inhibit the proliferation and induce the apoptosis of Dox-resistant osteosarcoma cells.

\section{Combination of Dox with $\beta$-Elemene Induced the Oxidative Stress of Dox- Resistant Osteosarcoma Cells}

To determine the effect of Dox combined with $\beta$-Elemene on oxidative stress in MG63/Dox and Saos-2/Dox cells, the production of ROS and GSH was detected. As indicated in Figure 4A-D, combination treatment remarkably increased ROS production, and reduced the level of GSH in MG63/Dox and Saos-2/Dox cells, compared with Dox treatment group. These data indicated that combination of Dox with $\beta$ Elemene could induce the oxidative stress in Dox-resistant osteosarcoma cells.

\section{$\beta$-Elemene Enhanced the Sensitivity of Saos-2/Dox Cells to Dox via Downregulation of Prx-I}

Peroxiredoxin (Prx) 1, an antioxidant protein, has been shown to be participated in protecting cancer cells against different 
A
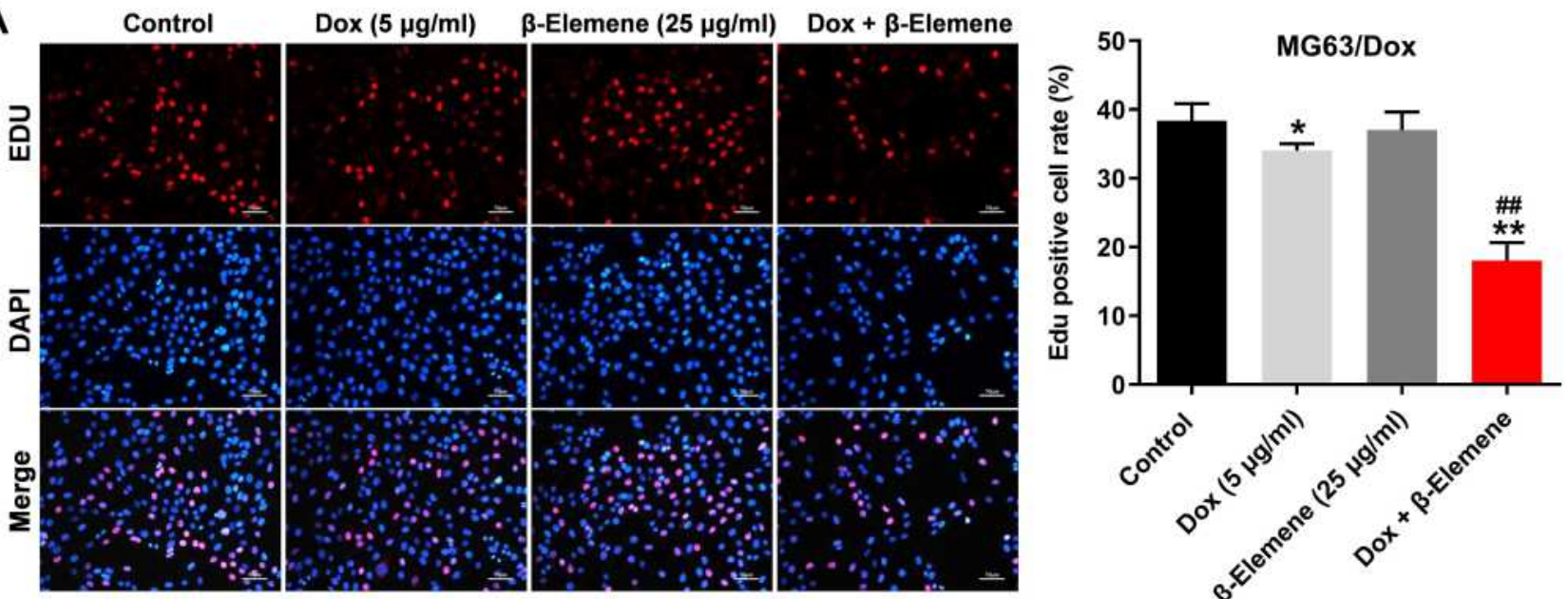

B
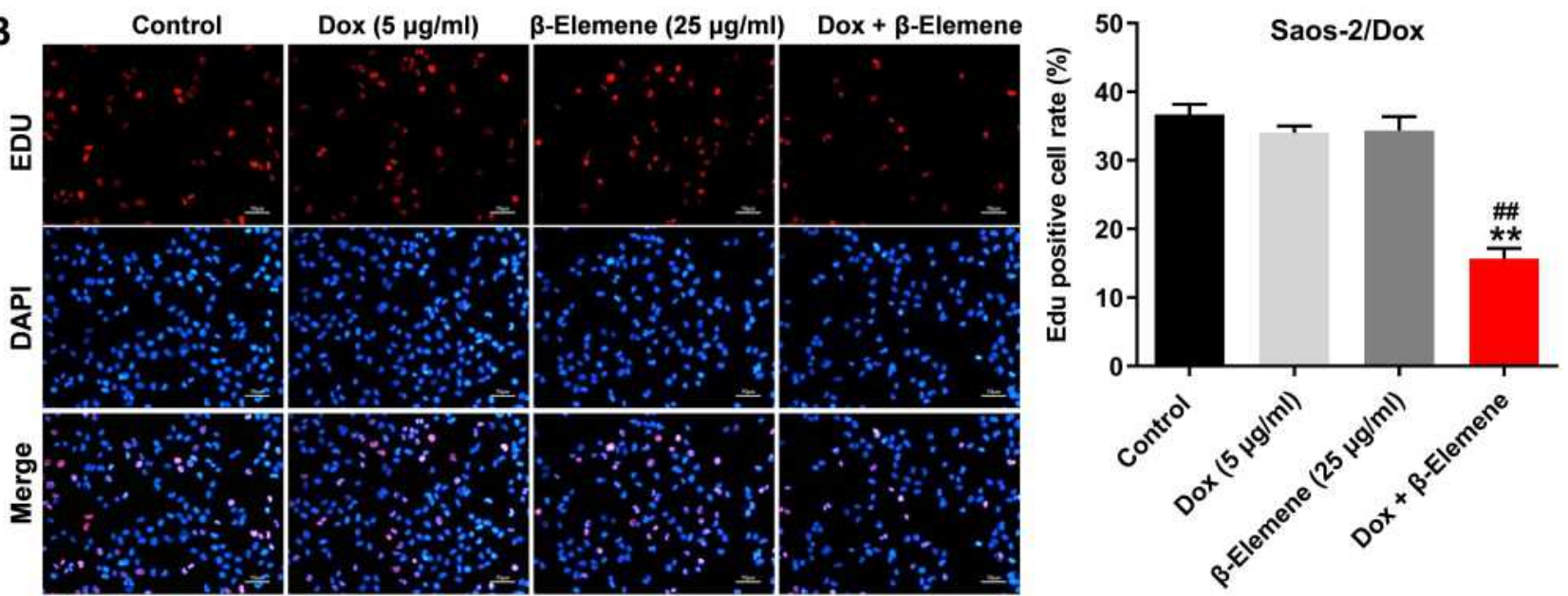

Figure 2 Combination of Dox with $\beta$-Elemene inhibited the proliferation of Dox-resistant osteosarcoma cells. (A) MG63/Dox cells or (B) Saos-2/Dox cells were treated with $5 \mu \mathrm{g} / \mathrm{mL}$ Dox or/and $25 \mu \mathrm{g} / \mathrm{mL} \beta$-Elemene for $48 \mathrm{~h}$. EdU staining assay was used to determine cell proliferation. $* \mathrm{P}<0.05$, $* * \mathrm{P}<0.0 \mathrm{I}$, compared with the control group; ${ }^{\# \prime} \mathrm{P}<0.0 \mathrm{l}$, compared with the Dox treatment group.

Abbreviations: Dox, doxorubicin; MG63/Dox, Dox-resistant MG63 cells; Saos-2/Dox, Dox-resistant Saos-2 cells.

therapeutic challenges. ${ }^{18}$ Western blot analysis showed that the expression of Prx-1 in MG63/Dox and Saos-2/Dox cells were much higher than that in parental MG63 and Saos-2 cells, indicating that Prx-1 might be involved in protecting Dox-resistant osteosarcoma cells against oxidative stress (Figure 5A and $\mathrm{B}$ ). In addition, $\beta$-Elemene or combination treatment significantly downregulated the expression of Prx-1 in MG63/Dox and Saos-2/Dox cells (Figure 5C and D).

To investigate whether $\beta$-Elemene enhanced the sensitivity of Dox-resistant osteosarcoma cells to Dox via downregulation of Prx-1, rescue experiments were performed. As shown in Figure 5E, the expression of Prx-1 was markedly increased in MG63/Dox and Saos-2/Dox cells after transfection with pcDNA3.1-Prx-1. In addition, overexpression of Prx-1 reversed the inhibitory effect of combination treatment on the viability of osteosarcoma cells (Figure 5F). Moreover, combination treatment-induced Prx-1 protein decrease was notably reversed by Prx-1 overexpression (Figure 5G). These results suggested that $\beta$-Elemene could enhance the sensitivity of osteosarcoma cells via downregulation of Prx-1.

\section{Combination of Dox with $\beta$-Elemene Inhibited the Tumorigenesis of Saos-2/ Dox Xenograft in vivo}

We next investigated the effect of combination in the Saos2/Dox xenograft mouse model in vivo. As revealed in Figure $6 \mathrm{~A}-\mathrm{C}$, Dox treatment reduced the tumor volume and tumor weight of Saos-2/Dox xenograft mice. As expected, combination treatment notably decreased the tumor volume and tumor weight of Saos-2/Dox xenograft 

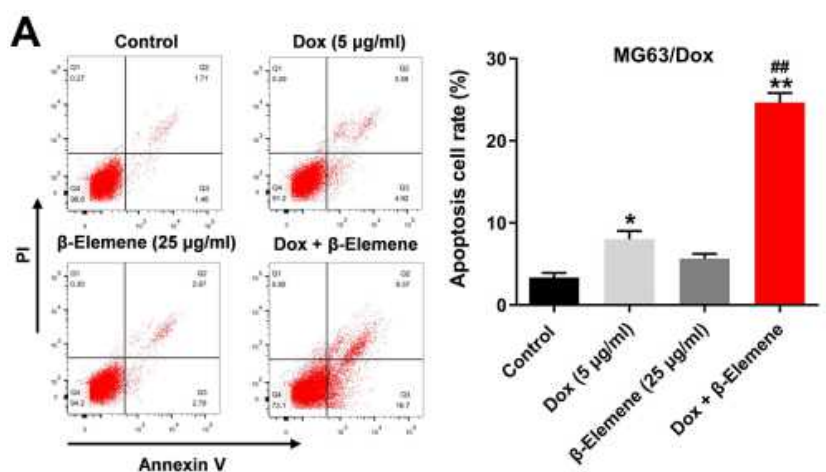

C

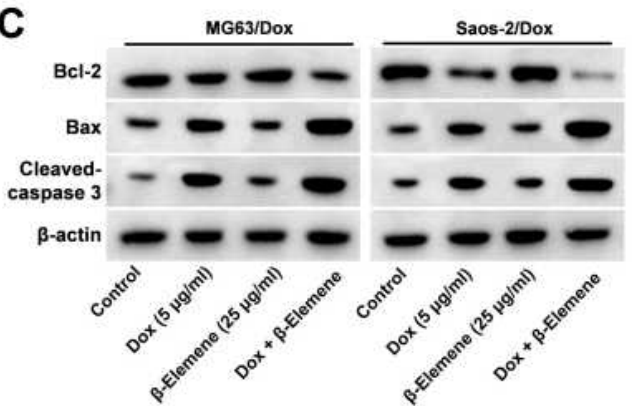

E

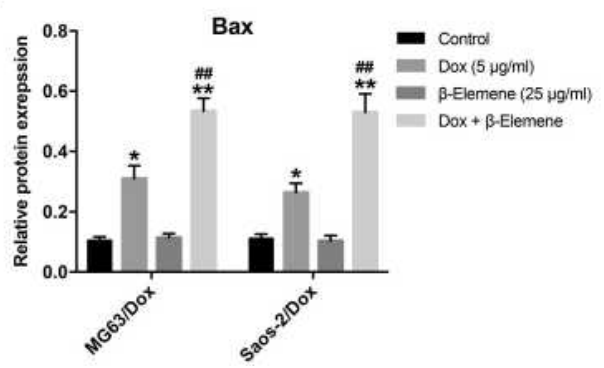

B
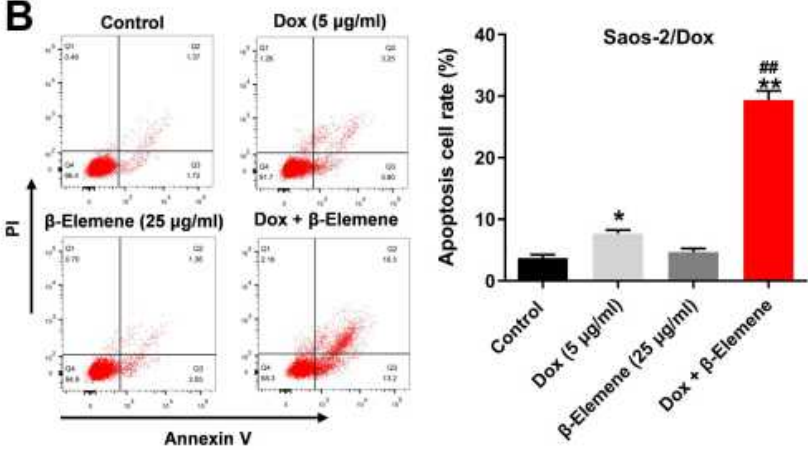

D

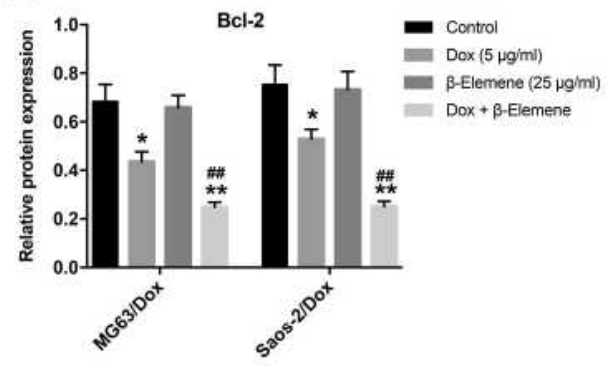

F

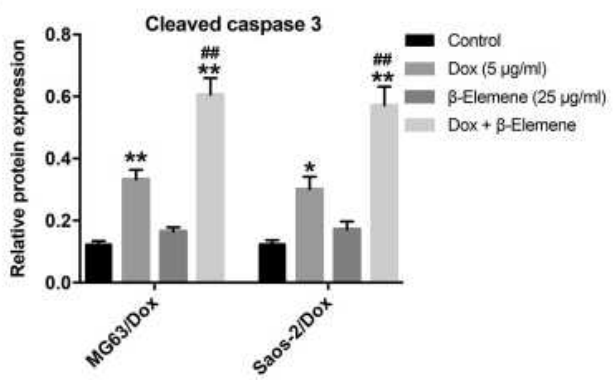

Figure 3 Combination of Dox with $\beta$-Elemene induced the apoptosis of Dox-resistant osteosarcoma cells. MG63/Dox and Saos-2/Dox cells were treated with $5 \mu$ g/mL Dox or/and $25 \mu \mathrm{g} / \mathrm{mL} \beta$-Elemene for $48 \mathrm{~h}$. (A and B) Apoptotic cells were measured by flow cytometry. (C) Expression levels of Bcl-2, Bax and cleaved caspase 3 in cells were detected with Western blotting. $\beta$-actin was used as an internal control. (D-F) The relative expressions of Bcl-2, Bax and cleaved caspase 3 in cells were quantified via normalization to $\beta$-actin. ${ }^{*} \mathrm{P}<0.05$, ${ }^{*} \mathrm{P}<0.01$, compared with the control group; ${ }^{\prime} \mathrm{P}<0.0 \mathrm{l}$, compared with the Dox treatment group.

Abbreviations: Dox, doxorubicin; MG63/Dox, Dox-resistant MG63 cells; PI, propidium iodide; Saos-2/Dox, Dox-resistant Saos-2 cells.

mice compared with Dox treatment group (Figure 6A-C). In addition, combination treatment significantly downregulated the expression of Prx-1 in tumor tissues compared with Dox treatment group (Figure 6D). Meanwhile, the results of CD31 IHC assay showed that significant reduction in CD31+ microvessel density (MVD) was observed in tumor tissues from the $\beta$-Elemene + Dox group compared to those from the control or Dox treatment group (Supplementary Figure 3A and B). However, no differences in CD31+ microvessel density (MVD) were detected between the control and $\beta$-Elemene treatment group (Supplementary Figure 3A and B). Collectively, combination of Dox with $\beta$-Elemene could inhibit the tumorigenesis and angiogenesis in Saos-2/Dox xenograft in vivo.

\section{Discussion}

In this study, we found that the combination of Dox with $\beta$-Elemene synergistically suppressed the proliferation of osteosarcoma cells. In addition, the combination of Dox with HHT induced apoptosis and oxidative stress in osteosarcoma cells via inhibition of Prx-1.

Dox, also known as adriamycin, has been considered as a first-line drug for a wide variety of cancer types, including osteosarcoma. ${ }^{19-22}$ However, chemoresistance is a primary cause of death in patients with metastatic or recurrent osteosarcoma. ${ }^{23}$ Thus, investigating how to decrease emergence of resistance and improve the efficacy of chemotherapeutic drugs might be important methods for treating osteosarcoma. ${ }^{24}$ Evidence has shown that the 
A
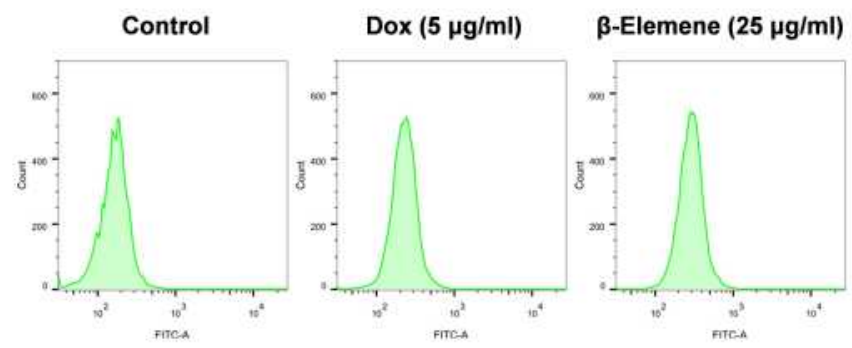

B
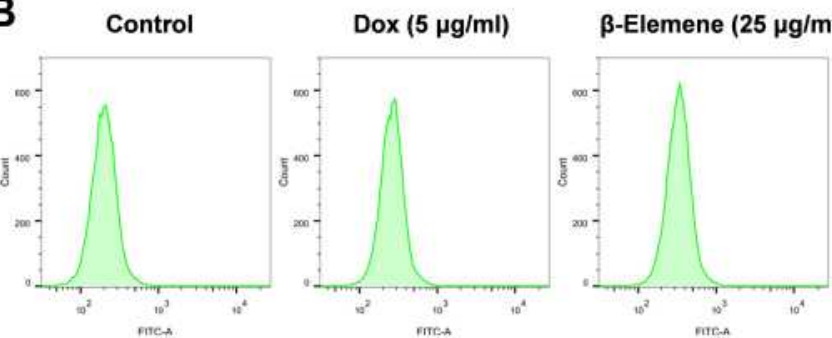

C

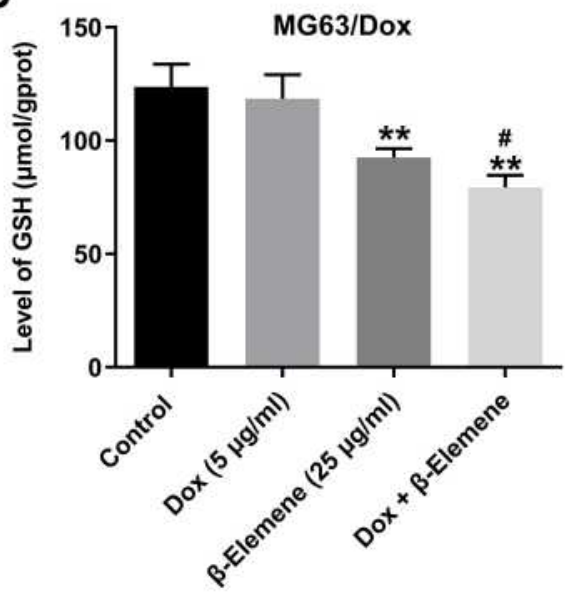

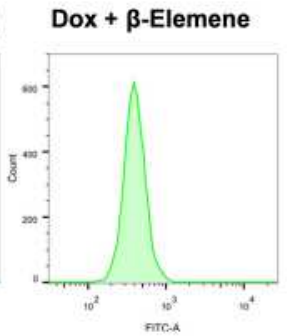
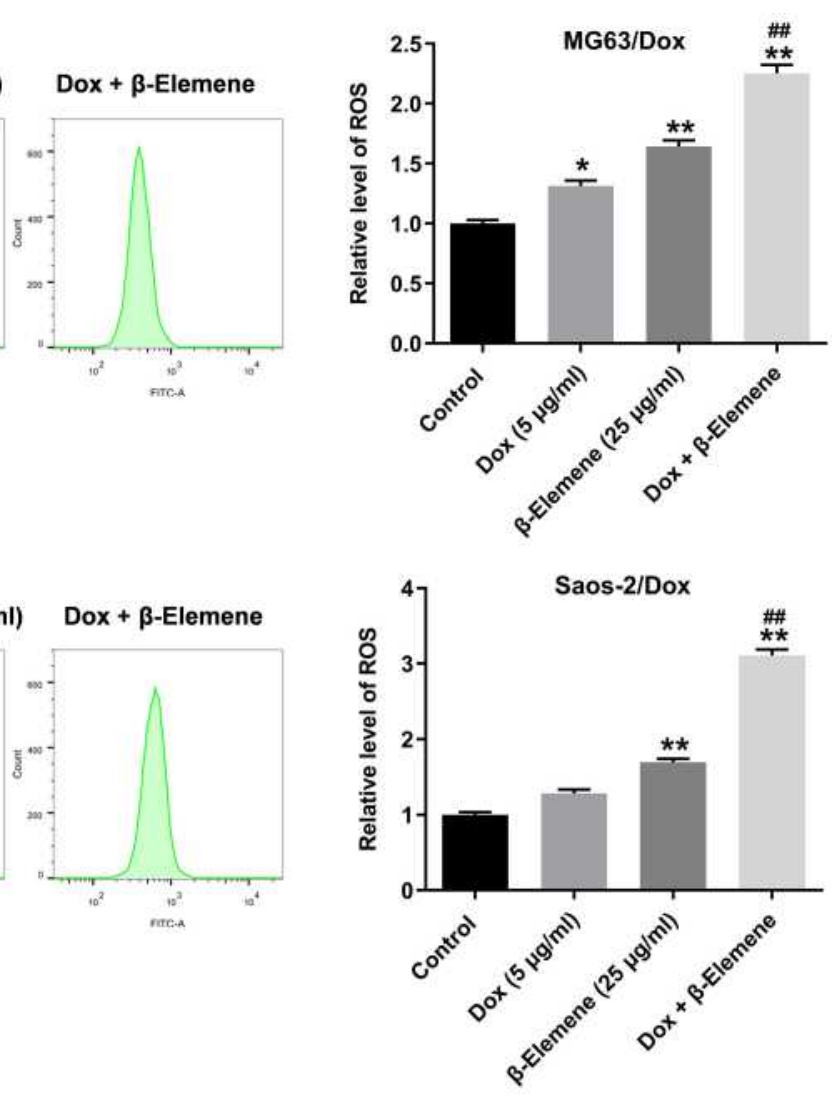

D

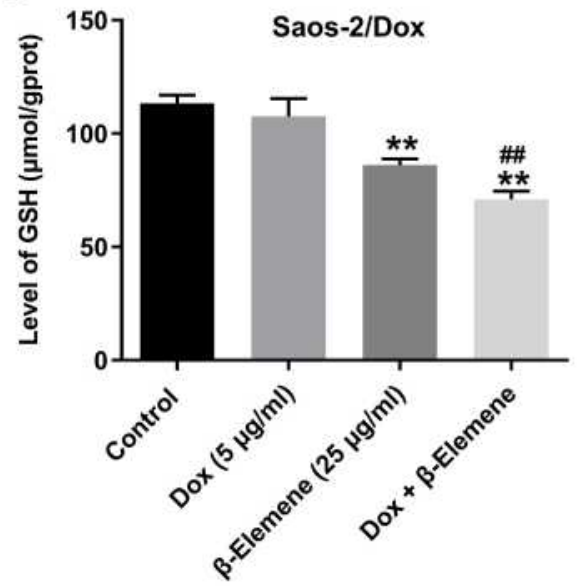

Figure 4 Combination of Dox with $\beta$-Elemene induced the oxidative stress in Dox-resistant osteosarcoma cells. MG63/Dox and Saos-2/Dox cells were treated with $5 \mu$ g/ $\mathrm{mL}$ Dox or/and $25 \mu \mathrm{g} / \mathrm{mL} \beta$-Elemene for $48 \mathrm{~h}$. (A and B) Flow cytometry was applied to assess the ROS production in MG63/Dox and Saos-2/Dox cells. (C and D) ELISA assay was used to detect the level of GSH in the supernatants of MG63/Dox and Saos-2/Dox cells. $* \mathrm{P}<0.05$, **P $<0.0$ I, compared with the control group; ${ }^{\#} \mathrm{P}<0.05$, ${ }^{\# \# P}<$ 0.0I, compared with the Dox treatment group.

Abbreviations: Dox, doxorubicin; GSH, glutathione; MG63/Dox, Dox-resistant MG63 cells; ROS, reactive oxygen species; Saos-2/Dox, Dox-resistant Saos-2 cells.

combination of chemotherapeutic drugs and traditional Chinese medicine in cancer therapies has the potential to decrease the emergence of resistance and improve the effectiveness of drug treatment. ${ }^{25,26}$ Liang et al found that $\beta$-Elemene could inhibit the proliferation of osteosarcoma cells via the inactivation of $\mathrm{PI} 3 \mathrm{~K} / \mathrm{Akt} / \mathrm{mTOR}$ pathway and upregulation of ROS production. ${ }^{15}$ In this study, we found that $\beta$-Elemene could inhibit the proliferation of Dox-resistant osteosarcoma cells via inhibiting ERK and p38 MAPK pathways. These data suggested that $\beta$ Elemene may inhibit osteosarcoma cell growth via different pathways. In addition, $\beta$-Elemene has been found to enhance the sensitivity of cancer cells to chemotherapeutic drugs, such as cisplatin, temozolomide. ${ }^{27,28} \mathrm{Zhu}$ et al 

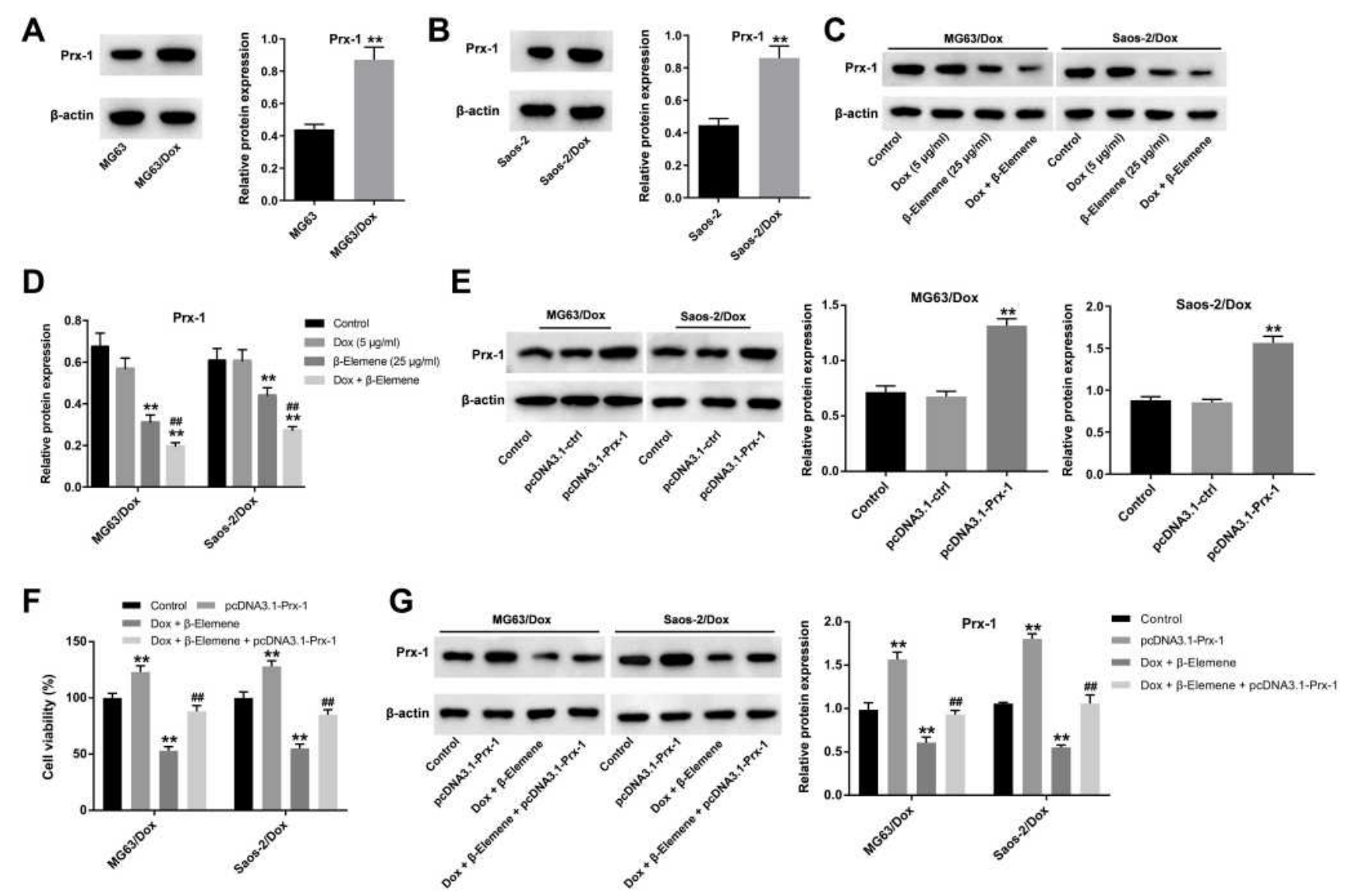

Figure 5 B-Elemene enhanced the sensitivity of Saos-2/Dox cells to Dox via downregulation of Prx-I. (A) Western blot assay was used to detect the expression of Prx-I in MG63 and MG63/Dox cells. $\beta$-actin was used as an internal control. **P < 0.01 , compared with the MG63 group. (B) Western blot assay was used to detect the expression of Prx-I in Saos-2 and Saos-2/Dox cells. $\beta$-actin was used as an internal control. **P < 0.0I, compared with the Saos-2 group. (C) MG63/Dox and Saos-2/Dox cells were treated with $5 \mu \mathrm{g} / \mathrm{mL}$ Dox or/and $25 \mu \mathrm{g} / \mathrm{mL} \beta$-Elemene for $48 \mathrm{~h}$. The expression level of Prx-I in MG63/Dox and Saos-2/Dox cells was detected with Western blotting. (D) The relative expression of Prx-I in cells was quantified via normalization to $\beta$-actin. **P $<0.0$ l, compared with the control group; ${ }^{\# \#} \mathrm{P}<0.01$, compared with the Dox treatment group. (E) Western blot analysis of Prx-I expression in MG63/Dox and Saos-2/Dox cells transfected with pcDNA3.I-Prx-I. **P < 0.0I, compared with the pcDNA3.I-ctrl group. (F) MG63/Dox and Saos-2/Dox were treated with $5 \mu \mathrm{g} / \mathrm{mL}$ Dox and $25 \mu \mathrm{g} / \mathrm{mL} \beta$-Elemene, or the combination of Dox and $\beta$-Elemene and pcDNA3.I-Prx-I for $48 \mathrm{~h}$. CCK-8 assay was used to detect cell viability. (G) Western blot analysis of Prx-I expression in MG63/Dox and Saos-2/Dox cells. **P < 0.0I, compared with the control group; ${ }^{\#} \mathrm{P}<0.01$, compared with the Dox $+\beta$-Elemene treatment group.

Abbreviations: Dox, doxorubicin; MG63/Dox, Dox-resistant MG63 cells; pcDNA3.I-ctrl, pcDNA3.I-control; Prx-I, peroxiredoxin I; Saos-2/Dox, Dox-resistant Saos-2 cells.

found that $\beta$-Elemene could reverse temozolomide resistance in glioblastoma stem-like cells. ${ }^{28} \mathrm{Li}$ et al indicated that $\beta$-Elemene could enhance the sensitivity of lung cancer cells to cisplatin via blocking cell cycle progression. ${ }^{29}$ In this study, we found that the inhibitory effects of Dox on the proliferation of Dox-resistant osteosarcoma cells were enhanced in the presence of $\beta$-Elemene. Moreover, we found that $\beta$-Elemene significantly enhanced the proapoptosis effect of Dox in Dox-resistant osteosarcoma cells. For the first time, we found that $\beta$-Elemene could enhance the sensitivity of osteosarcoma cells to Dox.

Evidence has shown that oxidative stress plays a pivotal role in cancer chemoresistance. ${ }^{30,31}$ Marinello et al found that metformin could enhance the sensitivity of Dox-resistant breast cancer cells to
Dox via inducing oxidative stress. ${ }^{32}$ In addition, Sun et al found that atovaquone could reverse Dox or cisplatin resistance in hepatocellular carcinoma by inducing oxidative stress. ${ }^{33}$ Cao et al indicated that natural borneol enhanced Dox-induced cell cycle arrest via triggering ROS-mediated signal. ${ }^{34}$ Consistent with our present results, we found that combination of Dox and $\beta$-Elemene significantly increased ROS production and reduced the level of GSH in Dox-resistant osteosarcoma cells, indicating that combination treatment could induce oxidative stress in Dox-resistant osteosarcoma cells.

In addition, increased levels of antioxidant enzymes are believed to contribute to chemoresistance. ${ }^{35}$ It has been shown that $\beta$-eudesmol enhanced chemosensitivity 

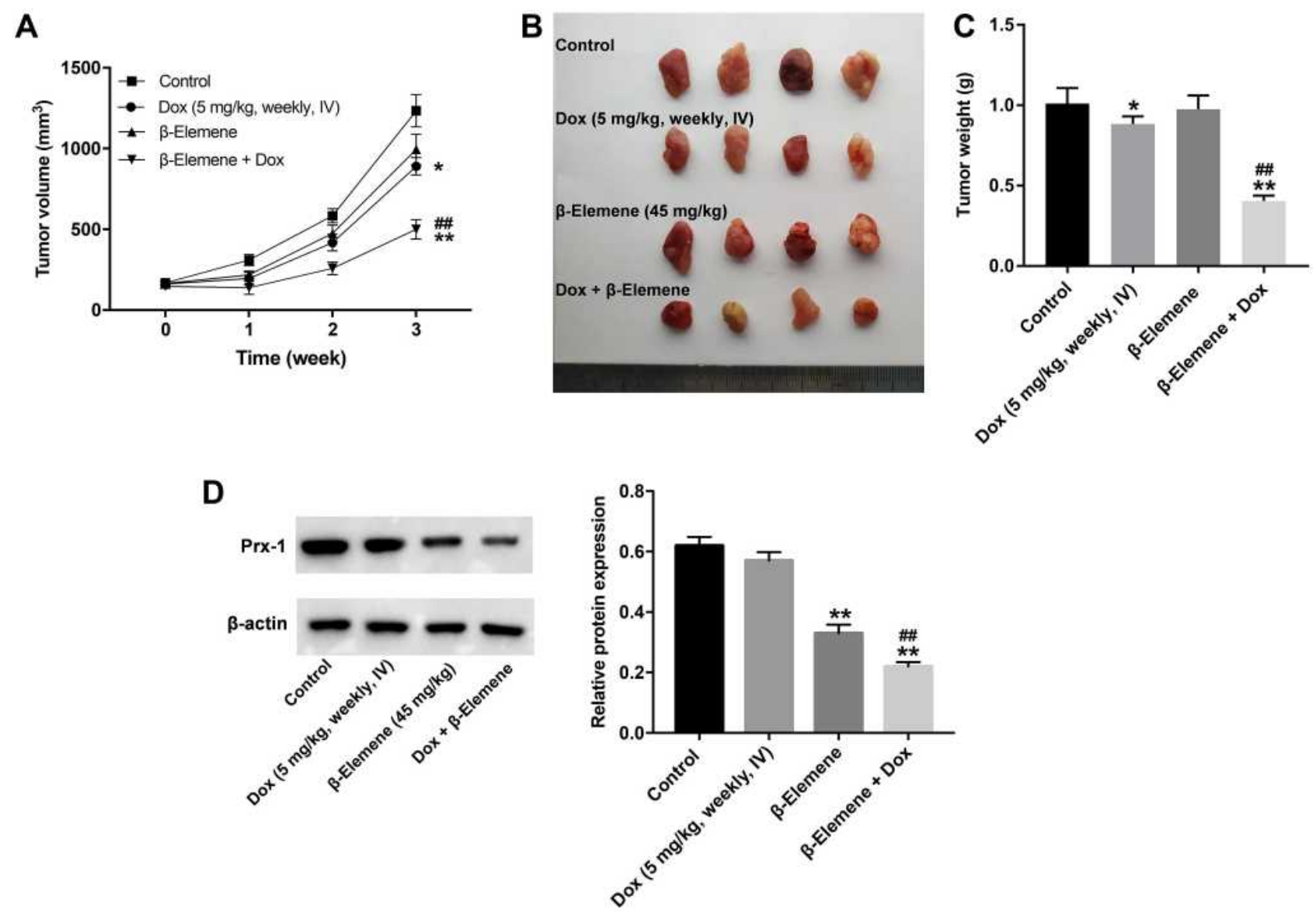

Figure 6 Combination of Dox with $\beta$-Elemene inhibited tumorigenesis in Saos-2/Dox xenograft in vivo. (A) Tumor volumes of mice were monitored at different time points. (B and C) Saos-2/Dox xenograft tumors in each group was pictured and weighted on day 2I. (D) Western blot analysis of Prx-I expression in tumor tissues. *P $<0.05$, **P $<$ $0.0 \mathrm{I}$, compared with the control group; ${ }^{\#} \mathrm{P}<0.0 \mathrm{I}$, compared with the Dox treatment group.

Abbreviations: Dox, doxorubicin; IV, intravenous injection.

to Dox in cholangiocarcinoma via suppression of antioxidant enzyme $\mathrm{NAD}(\mathrm{P}) \mathrm{H}$-quinone oxidoreductase $1 .^{36}$ Zou et al found that $\beta$-Elemene could drive radiosensitivity in non-small-cell lung cancer via inhibition of Prx- $1 .{ }^{37}$ Our data found that the expression of Prx-1 was notably upregulated in Dox-resistant osteosarcoma cells. Significantly, $\beta$-Elemene or combination treatment downregulated the expression of Prx-1 in Dox-resistant osteosarcoma cells, suggesting that combination treatment could inhibit the antioxidant capacity of Doxresistance osteosarcoma cells. These data indicated that $\beta$-Elemene could enhance the sensitivity of osteosarcoma cells to Dox via inhibition of Prx-1.

In this study, we also found that the combination of Dox with $\beta$-Elemene could inhibit the angiogenesis in Saos-2/Dox xenograft in vivo. Angiogenesis is an important physiological process required for tumor growth. ${ }^{38}$ Evidence has shown that tumor cells could affect the tumor microenvironment via releasing extracellular vesicles, thereby promoting tumor angiogenesis. ${ }^{39}$ Thus, further study is needed to investigate whether combined Dox with $\beta$-Elemene can inhibit tumor angiogenesis via affecting the secretion of tumor-derived extracellular vesicles.

\section{Conclusion}

Collectively, $\beta$-Elemene could reverse Dox resistance in Dox-resistant osteosarcoma cells via inhibition of Prx-1. Therefore, $\beta$-Elemene combined with Dox might be considered as a therapeutic method for the treatment of Doxresistant osteosarcoma.

\section{Data Sharing Statement}

The datasets used and/or analyzed during the current study are available from the corresponding authors on reasonable requests. 


\section{Ethics Approval and Consent to Participate}

All animal procedures were approved by the Institutional Animal Care and Use Committee of Renmin Hospital of Wuhan University Renmin Hospital of Wuhan University and the guidelines for welfare and treatment of the laboratory animals were following to National Institutes of Health guide for the care and use of laboratory animals.

\section{Funding}

No funding was received.

\section{Disclosure}

The authors declare no competing interests.

\section{References}

1. Sangle NA, Layfield LJ. Telangiectatic osteosarcoma. Arch Pathol Lab Med. 2012;136(5):572-576. doi:10.5858/arpa.2011-0204-RS

2. Sun K, Gong C, Peng H, et al. High CCL5 expression is associated with osteosarcoma metastasis and poor prognosis of patients with osteosarcoma. Mol Med Rep. 2017;16(5):6953-6957. doi:10.3892/ mmr.2017.7458

3. Chen J, Hu Y, Zhang L, et al. Alginate oligosaccharide DP5 exhibits antitumor effects in osteosarcoma patients following surgery. Front Pharmacol. 2017;8:623. doi:10.3389/fphar.2017.00623

4. Fu D, Lu C, Qu X, et al. LncRNA TTN-AS1 regulates osteosarcoma cell apoptosis and drug resistance via the miR-134-5p/MBTD1 axis. Aging (Albany NY). 2019;11(19):8374-8385. doi:10.18632/aging. 102325

5. Sun R, Muheremu A, Hu Y. miRNA-30c can be used as a target in the diagnosis and treatment of osteosarcoma. Onco Targets Ther. 2018;11:9091-9099. doi:10.2147/OTT.S181177

6. Wang L, Yang L, Lu Y, et al. Osthole induces cell cycle arrest and inhibits migration and invasion via PTEN/Akt pathways in osteosarcoma. Cell Physiol Biochem. 2016;38(6):2173-2182. doi:10. $1159 / 000445573$

7. Siegel RL, Miller KD, Jemal A. Cancer statistics, 2019. CA Cancer J Clin. 2019;69(1):7-34. doi:10.3322/caac.21551

8. Wan Y, Xu L, Zhuo N, et al. The clinical significance of neoadjuvant chemotherapy in improving the drug resistance of osteosarcoma. Minerva Med. 2017;108(5):479-481. doi:10.23736/S0026-4806.17. 05122-9

9. Yu L, Meng M, Bao Y, et al. miR-1301/TRIAP1 axis participates in epirubicin-mediated anti-proliferation and pro-apoptosis in osteosarcoma. Yonsei Med J. 2019;60(9):832-841. doi:10.3349/ ymj.2019.60.9.832

10. Zhang B, Zhang Y, Li R, et al. The efficacy and safety comparison of first-line chemotherapeutic agents (high-dose methotrexate, doxorubicin, cisplatin, and ifosfamide) for osteosarcoma: a network meta-analysis. J Orthop Surg Res. 2020;15(1):51. doi:10.1186/ s13018-020-1576-0

11. Rivankar S. An overview of doxorubicin formulations in cancer therapy. J Cancer Res Ther. 2014;10(4):853-858. doi:10.4103/09731482.139267

12. Li Y, Hou H, Zhang P, Zhang Z. Co-delivery of doxorubicin and paclitaxel by reduction $/ \mathrm{pH}$ dual responsive nanocarriers for osteosarcoma therapy. Drug Deliv. 2020;27(1):1044-1053. doi:10.1080/ 10717544.2020.1785049
13. Cao C, Wang Q, Liu Y. Lung cancer combination therapy: doxorubicin and $\beta$-elemene co-loaded, $\mathrm{pH}$-sensitive nanostructured lipid carriers. Drug Des Devel Ther. 2019;13:1087-1098. doi:10.2147/ DDDT.S198003

14. Chen P, Li X, Zhang R, et al. Combinative treatment of $\beta$-elemene and cetuximab is sensitive to KRAS mutant colorectal cancer cells by inducing ferroptosis and inhibiting epithelial-mesenchymal transformation. Theranostics. 2020;10(11):5107-5119. doi:10.7150/thno.44 705

15. Liang D, Yang M, Guo B, et al. HIF-1 $\alpha$ induced by $\beta$-elemene protects human osteosarcoma cells from undergoing apoptosis. J Cancer Res Clin Oncol. 2012;138(11):1865-1877. doi:10.1007/ s00432-012-1256-5

16. Tang CY, Zhu LX, Yu JD, et al. Effect of $\beta$-elemene on the kinetics of intracellular transport of d-luciferin potassium salt (ABC substrate) in doxorubicin-resistant breast cancer cells and the associated molecular mechanism. Eur J Pharm Sci. 2018;120:20-29. doi:10.1016/j. ejps.2018.04.037

17. Chou TC, Talalay P. Quantitative analysis of dose-effect relationships: the combined effects of multiple drugs or enzyme inhibitors. Adv Enzyme Regul. 1984;22:27-55. doi:10.1016/0065-2571(84) 90007-4

18. He T, Banach-Latapy A, Vernis L, et al. Peroxiredoxin 1 knockdown potentiates $\beta$-lapachone cytotoxicity through modulation of reactive oxygen species and mitogen-activated protein kinase signals. Carcinogenesis. 2013;34(4):760-769. doi:10.1093/carcin/bgs389

19. Chen C, Lu L, Yan S, et al. Autophagy and doxorubicin resistance in cancer. Anticancer Drugs. 2018;29(1):1-9. doi:10.1097/CAD.000 0000000000572

20. Al-Malky HS, Al Harthi SE, Osman AM. Major obstacles to doxorubicin therapy: cardiotoxicity and drug resistance. J Oncol Pharm Pract. 2020;26(2):434-444. doi:10.1177/107815521987 7931

21. Lorusso D, Sabatucci I, Maltese G, et al. Treatment of recurrent ovarian cancer with pegylated liposomal doxorubicin: a reappraisal and critical analysis. Tumori. 2019;105(4):282-287. doi:10.1177/ 0300891619839308

22. Gazzano E, Buondonno I, Marengo A, et al. Hyaluronated liposomes containing H2S-releasing doxorubicin are effective against P-glycoprotein-positive/doxorubicin-resistant osteosarcoma cells and xenografts. Cancer Lett. 2019;456:29-39. doi:10.1016/j.canlet.20 19.04.029

23. Ma W, Yang L, Liu H, et al. PAXX is a novel target to overcome resistance to doxorubicin and cisplatin in osteosarcoma. Biochem Biophys Res Commun. 2020;521(1):204-211. doi:10.1016/j. bbrc.2019.10.108

24. Buondonno I, Gazzano E, Tavanti E, et al. Endoplasmic reticulum-targeting doxorubicin: a new tool effective against doxorubicin-resistant osteosarcoma. Cell Mol Life Sci. 2019;76 (3):609-625. doi:10.1007/s00018-018-2967-9

25. Fu Z, Ma K, Dong B, et al. The synergistic antitumor effect of huaier combined with 5-florouracil in human cholangiocarcinoma cells. BMC Complement Altern Med. 2019;19(1):203. doi:10.1186/ s12906-019-2614-5

26. Guo W, Tan HY, Chen F, Wang N, Feng Y. Targeting cancer metabolism to resensitize chemotherapy: potential development of cancer chemosensitizers from traditional Chinese medicines. Cancers (Basel. 2020;12(2). doi:10.3390/cancers12020404

27. Li QQ, Lee RX, Liang H, et al. $\beta$-Elemene enhances susceptibility to cisplatin in resistant ovarian carcinoma cells via downregulation of ERCC-1 and XIAP and inactivation of JNK. Int J Oncol. 2013;43 (3):721-728. doi:10.3892/ijo.2013.1996

28. Zhu TZ, Li XM, Luo LH, et al. $\beta$-elemene inhibits stemness, promotes differentiation and impairs chemoresistance to temozolomide in glioblastoma stem-like cells. Int J Oncol. 2014;45(2):699-709. doi:10.3892/ijo.2014.2448 
29. Li QQ, Wang G, Huang F, et al. Sensitization of lung cancer cells to cisplatin by $\beta$-elemene is mediated through blockade of cell cycle progression: antitumor efficacies of $\beta$-elemene and its synthetic analogs. Med Oncol. 2013;30(1):488. doi:10.1007/s12032013-0488-9

30. Zhan M, Wang H, Xu SW, et al. Variants in oxidative stress-related genes affect the chemosensitivity through Nrf2-mediated signaling pathway in biliary tract cancer. EBioMedicine. 2019;48:143-160. doi:10.1016/j.ebiom.2019.08.037

31. Pires BRB, Panis C, Alves VD, et al. Label-free proteomics revealed oxidative stress and inflammation as factors that enhance chemoresistance in luminal breast cancer. Oxid Med Cell Longev. 2019;2019:5357649. doi:10.1155/2019/ 5357649

32. Marinello PC, Panis C, Silva TNX, et al. Metformin prevention of doxorubicin resistance in MCF-7 and MDA-MB-231 involves oxidative stress generation and modulation of cell adaptation genes. Sci Rep. 2019;9(1):5864. doi:10.1038/s41598-01942357-w

33. Sun Y, Xu H, Chen X, Li X, Luo B. Inhibition of mitochondrial respiration overcomes hepatocellular carcinoma chemoresistance. Biochem Biophys Res Commun. 2019;508(2):626-632. doi:10.1016/ j.bbrc.2018.11.182
34. Cao WQ, Li Y, Hou YJ, et al. Enhanced anticancer efficiency of doxorubicin against human glioma by natural borneol through triggering ROS-mediated signal. Biomed Pharmacother. 2019;118:109261. doi:10.1016/j.biopha.2019.109261

35. Bur H, Haapasaari KM, Turpeenniemi-Hujanen T, et al. Oxidative stress markers and mitochondrial antioxidant enzyme expression are increased in aggressive Hodgkin lymphomas. Histopathology. 2014;65(3):319-327. doi:10.1111/his.12389

36. Srijiwangsa P, Ponnikorn S, Na-Bangchang K. Effect of $\beta$-Eudesmol on NQO1 suppression-enhanced sensitivity of cholangiocarcinoma cells to chemotherapeutic agents. BMC Pharmacol Toxicol. 2018;19 (1):32. doi:10.1186/s40360-018-0223-4

37. Zou K, Li Z, Zhang Y, et al. $\beta$-Elemene enhances radiosensitivity in non-small-cell lung cancer by inhibiting epithelial-mesenchymal transition and cancer stem cell traits via Prx-1/NF-kB/iNOS signaling pathway. Aging (Albany NY). 2020;12.

38. Albini A, Bruno A, Noonan DM, Mortara L. Contribution to tumor angiogenesis from innate immune cells within the tumor microenvironment: implications for immunotherapy. Front Immunol. 2018;9:527. doi:10.3389/fimmu.2018.00527

39. Yin Z, Li C, Wang J, Xue L. Myeloid-derived suppressor cells: roles in the tumor microenvironment and tumor radiotherapy. Int J Cancer. 2019;144(5):933-946. doi:10.1002/ijc.31744

\section{Publish your work in this journal}

OncoTargets and Therapy is an international, peer-reviewed, open access journal focusing on the pathological basis of all cancers, potential targets for therapy and treatment protocols employed to improve the management of cancer patients. The journal also focuses on the impact of management programs and new therapeutic agents and protocols on patient perspectives such as quality of life, adherence and satisfaction. The manuscript management system is completely online and includes a very quick and fair peer-review system, which is all easy to use. Visit http://www.dovepress.com/ testimonials.php to read real quotes from published authors. 